\title{
The Origin and Characteristics of the Image of the Aerial Spirits
}

\author{
Eugenia Smagina \\ Senior Research Fellow, Institute of Oriental Studies, Russian Academy of \\ Sciences, Moscow, Russia \\ esmagi54.54@mail.ru
}

\begin{abstract}
The parallels between the books of the Enoch cycle and the Coptic literature have not yet been fully investigated, and meanwhile they allow us to find out some data on the origin and meaning of the books of Enoch. For example, the Coptic Encomium to the Four Living Creatures from the Pierpont Morgan Library has a section which must be considered as a very close retelling of one episode from the 2nd (Slavonic) Book of Enoch. Subsequently, the image of four animals influenced the description of zoomorphic mythological characters, the so-called "leontocephals", in the apocryphal literature. In the encomium there are a number of parallels with the and Enoch, which allow to determine more precisely the date and features of this pseudepigraphon.
\end{abstract}

\section{Keywords}

2 Enoch - Pseudepigrapha - Coptic literature - Leontocephal - Elements Manichaeism

The "more than enigmatic"1 second book of Enoch book contains parallels in a Coptic text, which allows to determine more precisely its place in the general context of the late Antique apocrypha. This text is the Encomium to Four Bodiless Living Creatures ascribed to St. John Chrysostom from the Codex M612 of

1 M.E. Stone, "Jewish Tradition, the Pseudepigrapha and the Christian West," in:idem, Apocrypha, Pseudepigrapha and Armenian Studies. Collected Papers, vol. I (OLA, 144), Leuven-ParisDudley, MA, 2006, pp. 41-6o, at p. 45 . 
the Pierpont Morgan Library. ${ }^{2}$ This encomium describes a remarkable episode from the legend of Enoch, included in the description of the heavenly feast:

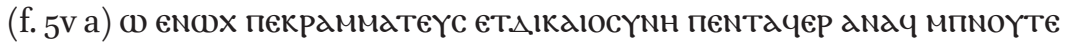

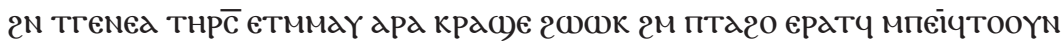
ZOOON

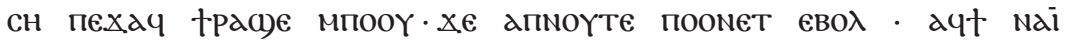

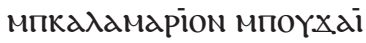

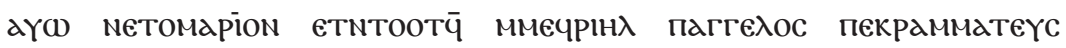

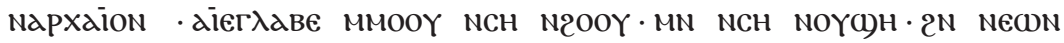
MாоYoein

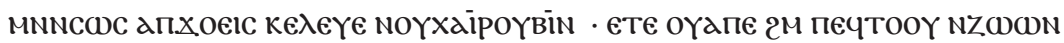

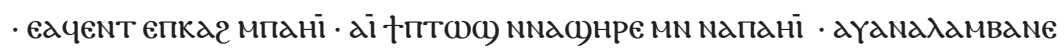
ммої еграї єтпе Nкесоп

дпNоүте гар таго ммої єрат гөн мпєеропос мпєхаіроүвім єтє пго

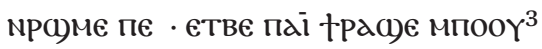

O Enoch, scribe of righteousness, who has pleased God among that entire generation, do you also rejoice in the establishment of these four living ${ }^{4}$ creatures? "Yes", he said, "I rejoice today since God exalted ${ }^{5}$ me and gave me the reed ${ }^{6}$ of salvation and the tomes which were in the hands of the angel Mefriêl, ${ }^{7}$ the ancient scribe. ${ }^{8}$ I copied them in sixty days and sixty nights in the aeons of light. ${ }^{9}$ After that the Lord (f. $5 \mathrm{vb}$ ) issued a command Morgan codices Coptici photographice expressi, vol. 45, Romae, 1922. The English translation is taken from the edition of Leuven: Homiletica from the Pierpont Morgan Library. Seven Coptic Homilies attributed to Basil the Great, John Chrysostom, and Euodius of Rome. Translated by D. Brakke, P. Chapman, Z. Pleše, J.R. Smith, M.C. Stone, C.S. Wansink, F. Weidmann. With an Introduction by R.A. Greer, L. Depuydt (csco, 525; Copt., 44), Lovanii, 1991, pp. 27-28, with some corrections.

3 Hyvernat, Bibliothecae Pierpont Morgan codices Coptici, p.10. DoI 10.1163/18177565bja1oorg

4 In the English translation, the word is absent.

5 In Homiletica from the Pierpont Morgan Library, p. 31, the English translation is transformed. But the verb пюळме єво $\lambda$ can mean move out; the meaning move up, exalt is also attested (W.E. Crum, The Coptic Dictionary, Oxford, 1979, p. 265A).

6 In Homiletica from the Pierpont Morgan Library, p. 31, is translated penholder.

$7 \quad$ The origin of the name is unclear.

8 In Homiletica from the Pierpont Morgan Library, p. 31, translated scribe of old.

9 In Homiletica from the Pierpont Morgan Library, p. 31, the translation is in six days and six nights according to the aeons of light. But $\mathrm{cH}$ is rather a variant of ce sixty (W.E. Crum, The Coptic Dictionary, Oxford, 1979, p. 368 B). This is confirmed by the aforementioned 
to a cherub, one of the four living creatures. After he had taken me to my homeland, ${ }^{10}$ I gave orders to my children and my relatives and was taken up to heaven again. God established me before the throne of the cherub, who is human-faced. ${ }^{11}$ Because of this I rejoice today."12

The similar episode is attested only in the 2nd Enoch, ch. X, where the name of the angel-scribe is Веревеилъ or Вревеилъ, Врьвоиль. ${ }^{13}$ In the original Greek text, from which the Slavic version was presumably made, there should have been variants ${ }^{*} B \varepsilon p \varepsilon \beta \varepsilon \eta \lambda, B \rho \varepsilon \beta \varepsilon \eta \lambda, B \rho \varepsilon \beta 0 \eta \lambda$. The form of the name in the encomium is мечрін $\lambda$. But the alternation of $B$ and $\varphi$ is a common phenomenon in Coptic, and the initial $M$ - may be the result of a phonetic dissimilation. Thus, we can assume the initial version * веврін $\lambda>*$ меврін $\lambda$ (or вечрін $\lambda$ ) > мечрін $\lambda$.

There is another possibility. If the long recension of and Enoch had a Syrian Vorlage,$^{14}$ the replacing b- by $\mathrm{m}$ - may be the result of a spelling error. ${ }^{15}$ It is in Syrian graphics that the letters bet and mem may be quite similar.

This parallel episode also throws light on the origin and dating of the and Enoch. It refutes the hypothesis of late origin of the book, ${ }^{16}$ as well as the opinion that it was not known to any of the ancient apocalyptic literatures. ${ }^{17}$

episode from the 2 Enoch, where the term 30 days and 30 nights is named, and then twice (соугоубъ) 30 days and 30 nights (G. Macaskill, The Slavonic Texts of 2 Enoch, LeidenBoston, 2013, p. 103. A. Vaillant, Le Livre des secrets d'Hénoch. Texte slave et traduction française (Textes publiés par l'Institut d'Études slaves, 4), Paris, 1952, pp. 26, 28). The preposition $2 \mathrm{~N}$ - most likely has a direct meaning here: in, at, and aeons of light mean the upper celestial spheres, where Enoch resides at this time. Cf. the use of this phrase in Gnostic texts.

10 Homiletica from the Pierpont Morgan Library, p. 31: the land of my relatives.

$11 \quad$ Homiletica from the Pierpont Morgan Library, p. 31: namely the human-faced one.

$12 \quad$ Homiletica from the Pierpont Morgan Library, p. 30-31.

13 Macaskill, The Slavonic Texts, p. 103; Vaillant, Le Livre des secrets, pp. 26, 28.

14 B. Lourié, "Slavonic Pseudepigrapha, Nubia, and the Syrians," in: The Other Side: Apocryphal Perspectives on Ancient Christian "Orthodoxies", ed. C. R. Moss, Ch. Tuckett, J. Verheyden, T. Nicklas (Novum Testamentum et Orbis Antiquus, 117), Göttingen, 2017, pp. 225-250.

It was my own guess, but recently, Basil Lourié made the same assumption in a letter to me dated July 7. I take this opportunity to thank Professor Lourié for providing me with these data.

Н.А. Мещерский, "К истории текста славянской книги Еноха” [N.A. Meshchersky, “То the history of the texts of the Slavonic book of Enoch"], Византийский временник /

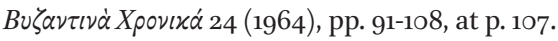

17 M.E. Stone, "Jewish Tradition, the Pseudepigrapha and the Christian West," in: idem, Apocrypha, Pseudepigrapha and Armenian Studies. Collected Papers, Vol. I (olA, 144), Leuven-Paris-Dudley, MA, 2006, pp. 41-6o, at p. 46. 
In addition, this angel appears in the encomium further, in an episode that has no parallel in 2nd Enoch. As one of the four "incorporeal living creatures" says, Enoch is put as a replacement for the angel Mefriêl in the role of the scribe of human deeds and the suppliant for the human race:

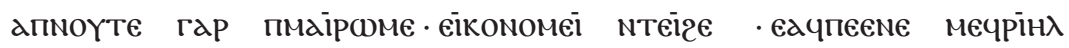

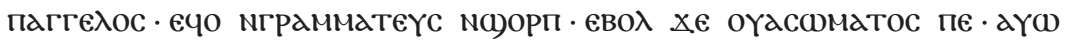

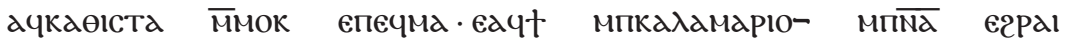

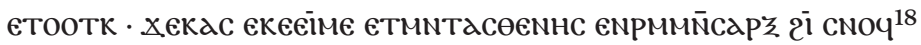

Indeed, God who loves humankind, arranged ${ }^{19}$ in this way. After he removed Mefriel the angel, who was scribe from the beginning, because he is bodiless, he established you (f. 1or b) in his place, having given you the spiritual reed ${ }^{20}$ so that you might take into account the weakness of people of flesh and blood. ${ }^{21}$

It is possible to suppose two ways of development:

1. This additional characteristic of Mefriêl is taken from some other apocryphal story of Enoch's cycle;

2. The addition was composed by the compiler of the encomium himself.

Besides, some other characters of the book of Enoch also find counterparts in Coptic texts, although not so obviously explicit.

In the Second book of Enoch, there are six-winged "flying spirits" carrying the chariots of the sun and the moon. ${ }^{22}$ In the long recension of the book (according to Vaillant, it came later than the brief one) appears two zoomorphic creatures, the twelve-winged birds Finex (Phoenix) and Khalkedriy (Chalcedrios).$^{23}$ Their similar role suggests a kinship with the "living creatures" of the encomium: the birds carry the chariot of the sun, as the four animals carry the throne-chariot of God. There is a certain discrepancy in the description of birds - they have head, tail and legs of a crocodile (коркодилоу), but in the same place it is said that they have "images" (образи) of a lion. Perhaps here we must suppose a later influence on the original text. The last feature could be borrowed from the description of the "living creature" which has the "image"

18 Hyvernat, Bibliothecae Pierpont Morgan codices, pp. 18-19.

19 In the English translation has made plans. Homiletica from the Pierpont Morgan Library, p. 34 .

20 In the English translation penholder. Homiletica from the Pierpont Morgan Library, p. 35 .

21 Homiletica from the Pierpont Morgan Library, pp. 34-35.

22 Macaskill, The Slavonic Texts, p. 71; Vaillant, Le Livre des secrets, pp. 12, 16.

23 Macaskill, The Slavonic Texts, p. 70; Vaillant, Le Livre des secrets, p. 90. 
( (ІІкCN) or "face" (20) of lion, but not completely consistent with the context. It seems that the compiler of the book had entirely borrowed this expression from some source (maybe Gnostic), so that it did not even fit well into the general context.

There is one more small detail which suggests continuity between the two texts. When describing the exultation of the birds and of the four "incorporeal beings" in the encomium, it is twice repeated that they "shake (or clap, splash; тдате, (репіzе) with their wings". ${ }^{24}$ The same expression we see in the long recension of and Enoch: when the Phoenix and Chalcedrios sing, "all the birds shake (flap, tremble; въстрепещжт) their wings". 25

There is reason to believe that at least the Greek version of 2nd Enoch had been written in Egypt. This is indicated, in particular, by the Egyptian names of the months in the datings: "... of the month Iyar (Иoyapca) in Hebrew, Phamenoth (Фаменоөа) in Egyptian ... Pharmut (Фармоута) in Egyptian, Nissan (Нисана) in Hebrew". 26

Such fantastic creatures, of course, are not uncommon in many mythologies. In the texts and iconography of Late Antiquity, the image of a lion-headed deity or demon is very common - from the figures in Graeco-Egyptian amulets and the Mesopotamian demon ${ }^{27}$ to the Meroitic deity, lion-headed serpent Apedemak. A close analogue to the King of Darkness we find in the Gnostic texts. In many Gnostic books, the Demiurge and lord of the material world (including the visible skies where the luminaries are located) Yaldabaoth-Saklas-Samael is often depicted as "lion-faced" or a "lion-faced serpent" - see, for example, the Apocryphon of John (ch. 69, 73, 136).

The mention of the twelve wings brings to mind the description of the supreme angel Samael in the midrash Pirqe de-Rabbi Eliezer, ch. 13: "Samael was a great ruler in heaven; and the seraphim had six wings, and Samael had twelve wings".

Meanwhile, in the Gnostic books, Samael is one of the names of the lord of the material world, Ialdabaoth-Saklas.

Note that the "Slavonic" book of Enoch reveals a connection with the earliest of this cycle, the 1st book of Enoch, and also contains motifs that can be called "proto-Gnostic" - obviously, early versions of some mythologumena developed later in Gnostic teachings.

\footnotetext{
24 Hyvernat, Bibliothecae Pierpont Morgan codices, pp. 4-5, 16; ff. 2v b - 3r a, 8v b.

25 Macaskill, The Slavonic Texts, p. 78; Vaillant, Le Livre des secrets, p. 92.

26 Macaskill, The Slavonic Texts, p. 250; Vaillant, Le Livre des secrets, p. 118.

27 See below, J. Naveh, Sh. Shaked, Amulets and Magic Bowls. Aramaic Incantations of Late Antiquity, Jerusalem, 1985, pp. 198-199.
} 
Apparently, the surviving Old Slavic version of the book is made from the Greek text, which, in turn, was compiled (or translated from some Semitic original) in Egypt. If we assume that the description was based on an iconographic image, then we can conclude that the Egyptian author or translator described the image, similar to the Manichaean demon (the body of a reptile with four limbs), as "like a crocodile".

There are several characters, especially attracting our attention, whose descriptions are preserved in Coptic sources or in other texts originating from Egypt. It is necessary to note that they are all connected with the element of air or have epithets "aerial, flying".

The King of Darkness, the leader of all the worlds of darkness, is one of the brightest figures in the Manichaean written sources. Descriptions in the two chapters of the treatise, present a lion-headed monster with eagle wings, a dragon's body, demon's limbs (that are, obviously human) and a fish tail. ${ }^{28}$ Similar descriptions, albeit more concise, have come down to us in some nonManichaean sources, for example, in the treatise Fihrist of the Arabic author an-Nadīm.

Nathalie Bosson, and earlier Henri-Charles Puech wrote about a "confusion": the Supreme demon is called or "King of Darkness" or "King of the world of Smoke". ${ }^{29}$ But it is unlikely to be called confusion: "darkness" means here one of the two general cosmic principles, and "smoke" is one of the five dark elements.

The Manichaean system of elements consists of two pentads, five elements of light and their dark counterparts. Smoke in this system is a counterpart of the light air.

Certainly, the Manichaean doctrine of elements has Greek roots. Firstly, the opinion about the entirely Hellenistic origin does not explain why the pair of light and darkness is "doubled": there are two main principles of light and darkness, and at the same time there are two opposite elements - light versus darkness - in the elemental pentads. Secondly, the theory of Hellenistic origin does not provide a basis for distinguishing the elements of wind and air/smoke.

Both questions are answered if we allow the influence of exegesis in of the first chapters of Genesis on this Manichaean teaching.

The exegetes in Talmud and Midrashim wrote about the existence of ten or eight primal principles which served as a basis for the creation. They identify

28 Kephalaia I, ed. H.-J.Polotsky \& A.Böhlig, Stuttgart, 1940, pp. 30.13-34.12, 76.15-79.12. The English translation cited will be that of I. Gardner, The Kephalaia of the Teacher. The Edited Coptic Manichaean Texts in Translation with Commentary, Leiden-New York-Köln, 1995.

29 N. Bosson, "Des deux royaumes du 'premier temps' (Kephalaia VI, VII, XXI, XXVII, LXIII et LXXIII de Mani en version française)," Mus, 108 (1995), pp. 1-38, at p. 20. 
these "things" with those listed in the first verses of Genesis, including wind and water (Gen 1:2), light and darkness (Gen 3-4). ${ }^{30}$

It can be argued that these are rather late sources. Already Philo in the first century AD makes attempts to reconcile the list of the primary substances in Gen 1 with the Greek philosophical teachings about the elements. In De opificio mundi VII, 29 - IX, 32, he identifies the biblical "darkness" (Gen 1:2) with the element of air. This proves that attempts to bring the Greek doctrine into line with the exegesis of the Bible were made much earlier than originated the Manichaeism.

It can be concluded that the Manichaean system of elements is the result of the adaptation of Hellenistic teachings to the biblical exegesis. This explains, in particular, the presence of elements of light and darkness in the pentads: cf. Gen. 1:45, where light and darkness are named among the primary substances. ${ }^{31}$

Why the function of supreme demon is performed here by the lord of smoke is another matter.

In the New Testament (Eph 2:2, 6:12) and in a number of early Christian sources, including those written in Egypt, the idea of the air as the abode of demons (or fallen angels, or the devil) is attested. Thus, the giant lord of demons dwelling in the air is mentioned in the Life of St. Anthony. ${ }^{32}$ The researcher notes that such a concept is absent in the Old Testament, it appears in Judaism only beginning with the apocrypha and rabbinic literature. ${ }^{33}$ It can be added: this is quite natural, because the concept of "air" and the word itself are absent in Biblical Hebrew and Aramaic. In the post-biblical literature, the Greek loanword is used: Hebr. אויר, Aram. אאר.

30 See e.g. Babylonian Talmud, Chagigah II, fol. 12a; Pirqe de-Rabbi Eliezer, Ch. 3 .

$31 \quad$ E. Smagina, "The Manichaean Cosmogonical Myth as a 're-written Bible," in: In Search of Truth: Augustine, Manichaeism and other Gnosticism: Studies for Johannes van Oort at Sixty. Ed. by J.-A. van den Berg, A, Kotzé, T. Nicklas \& M. Scopello, Leiden-Boston, 2011, pp. 201-216, at pp. 209-210.

32 See J. Daniélou, "Les démons de l'air dans la 'Vie d'Antoine'," in: Antonius magnus eremita, 356-195: Studia ad antiquum monachismum spectantia, ed. B. Steidle (Studia Anselmiana, 38), Rome, 1956, pp. 136-147; G. Garitte, S. Antonii vitae versio Sahidica (CSCO, 117; Copt., 13), Paris, 1949, pp. 30, 32, 35, 70; W. Beltz, "Die koptischen Zauberpapyri der PapyrusSammlung der Staatlichen Museen zu Berlin. Mit Abbildungen 6-11," Archiv für Papyrusforschung und verwandte Gebiete, 29 (1983), ss. 59-86, here S. 61; Macaskill, The Slavonic Texts, p. 88; Vaillant, Le Livre des secrets, p. 99.

33 Daniélou, "Les démons", pp. 136-147.

34 J. Levy, Neuhebräisches und Chaldäisches Wörterbuch über die Talmudim und Midrashim. 4 Bde, Berlin-Wien, 1924, Bd. 1., S. 15 B. 
Thus, the definition of Manichaean demon as the king of smoke is due to the fact that his prototype was an early Christian apocryphal personage - a demon (devil) dwelling in the air.

The images of other Manichaean deities or dark powers are more or less abstract. At best, their attributes are listed: crown, weapons, etc. See, for example, excerpts from Manichaean texts quoted by Augustine. But the zoomorphic image of the King of darkness in two chapters of the Kephalaia and in other texts is presented very visually and in detail. In the treatise these sections look like a parenthesis going back rather to an iconography than to a written source. This impression is enhanced if we trace the parallels to this image which can be found in other written and iconographic monuments of the Late Antiquity.

But the closest analogue to the description of the zoomorphic King of Darkness we find in Mandaean texts. The book Ginza, ch.12.6, contains a very similar description of the supreme demon. ${ }^{35}$ The zoomorphic Mandaean ruler of darkness, not only in appearance, but also in properties, shows a close resemblance to the Manichaean one, which allows to suppose a genetic affinity. Puech believes that the description of the king of demons in the Mandaean book goes back to these chapters of the Kephalaia. ${ }^{36}$ Moreover, it helps to gain better understanding of some places in the Manichaean treatise. So, the lines about the limited knowledge of the King of Darkness ${ }^{37}$ present some difficulty for translation, and in Ginzâ this property is described more intelligibly: "But he is unwise, stupid, his thoughts are confused, and he knows neither the first nor the last". ${ }^{8}$ Cf. the Gnostic text Exegesis of the Soul (ch. IV, 128, 25-26), a description of the offspring that the Soul spawned after the fall: they are deaf, blind, and sick, "their mind is in disorder". 39

In addition, in the Mandaean description, the motif of bisexuality of demons is more clearly expressed: the supreme demon is endowed with both male and female attributes. ${ }^{40}$

35 Ginzâ. Der Schatz oder das große Buch der Mandäer. Übersetzt und erklärt von M. Lidzbarski, Göttingen, 1925, S. 278; Th. Nöldeke, "Ein mandäischer Traktat," in: Aufsätze zur Kultur-und Sprachgeschichte vornehmlich des Orients. Ernst Kuhn zum 70. Geburtstage am 7. Februar 1916 gewidmet von Freunden und Schülern, hrsg. von I. Scherman, C. Bezold. München, 1916, S. 131-138, S. 135 and Anm. 6.

36 H.-Ch. Puech, Le manichéisme. Son fondateur, sa doctrine, Paris, 1949, p. 164.

$37 \quad$ Kephalaia I, ed. Polotsky, Böhlig, p. 32.11-13.

38 I.e. he does not possess the highest knowledge of the beginning and the end of the world. Ginzâ, S. 278.4.

39 M. Krause, P. Labib, Gnostische und hermetische Schriften aus Codex II und Codex VI, Glückstadt, 1971, S. 68.

$40 \quad$ Ginzâ, S. 278.31-33. 
In an Aramaic spell from Mesopotamia, the description of the lion-headed lord of demons named Bagdânâ Azizzâ reveals some similarities with the Manichaean text. ${ }^{41} \mathrm{Cf}$. the name of the power of darkness in the Middle Iranian Manichaean texts from Turfan: $A z$.

Strictly speaking, the image of a lion-headed winged dragon can go back to religious and mystical teaching of the Late Antiquity. This is a very similar cosmic deity in the Orphic Theogony (not earlier than 500 BC), according to Jerome and Hellanicus, in the narration of the Neo-Platonist Damascius. In this text, one can find not only the deity of the elements, very similar to the King of Darkness, but also the idea of a certain personified bisexual substance enclosing the material cosmos: Chronos (the lion-headed winged dragon) and Ananke-Adrastea. Perhaps this is where originates the Gnostic and Manichaean concept of Matter (in Syrian sources - Sin, feminine word) as the female embodiment of the dark principle.

One of the religious teachings of this time represents in its iconography, as researchers have noticed long ago, ${ }^{42}$ a close analogue of the King of Darkness as depicted in Manichaean sources. This is a Mithraic deity, conventionally called Leontocephalus, Aeon or Deus aeternus. There are many statues and reliefs of the "Mithraic Aeon" (since the second century AD and later). He is represented as a lion-headed man, winged (usually with four wings), entwined with a huge snake and holding a key, a torch or a staff. Sometimes he stands on the sphere, in some images there are signs of zodiac. By his appearance and attributes, Leontocephalus seems to be a cosmic deity, lord of the celestial spheres. ${ }^{43}$ The image of this deity, obviously, served as a prototype for describing the King of Darkness, improved later according to the five elements of the Manichaean system.

41 J. Naveh, Sh. Shaked, Amulets and Magic Bowls. Aramaic Incantations of Late Antiquity, Jerusalem, 1985, pp. 198-199.

42 F. Cumont, Textes et monuments figurés relatifs aux mystères de Mithra, 2 vols., Bruxelles, 1899, vol. I, pp. 77-78. It should be noted that F. Cumont based this observation solely on heresiological sources, the Manichaean texts were not yet found.

43 R. Pettazzoni, "La figura mostruosa del Tempo nella religione mitriaca," L'Antiquité classique, 18 (1949), pp. 265-277. For more about the King of darkness and "Mithraic Aeon”, see: Е.Б. Смагина, “Эллинистическое божество Паредрос и его эволюция” [E. B. Smagina, "The Hellenistic deity Paredros and his evolution"], in: Древний Египет: язык - культура - сознание. По материалам египтологической конферениии 1213 мapma 1998 2. [The Ancient Egypt: language - culture - mentality. By the materials of the Egyptological conference 12.-13. March 1998], Moscow, 1999, pp. 211-219; Е. Б. Смагина, “Истоки представлення о манихейском царе демонов” [Е. B. Smagina, “The sources of the image of the Manichaean King of demons"], Вестник древней истории [Journal of Ancient History] (1993) Nr 4, pp. 40-58. 
Late antique origins of the image of a lion-headed demon are also confirmed by the materials of magical texts. Images of deities with a lion's head on amulets from Egypt are quite common. ${ }^{44}$

Number 1 in the two-volume edition of Greek-speaking magic papyri from the Roman Egypt presents the papyrus of supposedly late fourth or fifth century. ${ }^{45}$ This is a fairly extensive collection of spells. One of the first texts in this papyrus is the spell of some deity or "aerial spirit" ( $\pi \nu \varepsilon \hat{u} \mu \alpha \dot{\alpha} \varepsilon \rho \hat{\omega} \delta \varepsilon c)$ called

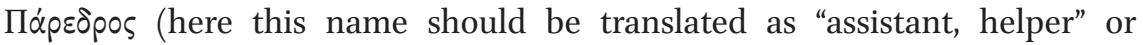
"associate"). 46

As far as can be judged by the description, the iconography of the figure on the amulet added to the "spell of Paredros" resembles the description of the Manichaean demon, but it is especially similar to the iconography of the Mithraistic Eon: "a lion-faced figure, holding in the left hand a celestial globe and a whip, and around him in a circle is a serpent biting its tail". ${ }^{47}$

In the Greek mythology $\pi \dot{\alpha} p \varepsilon \delta \rho \circ \zeta$ is the name of lower deities, personal "helpers" of a man. Since the Hellenistic epoch, Egyptian gods may also play this role. By its function in the spell, the magic Accomplice certainly fits this definition: it is the satellite spirit, an attendant serving the one who summoned him. Irenaeus mentions that the "mystical priests", followers of Simon Magus, often call "home spirits" ( $\pi \dot{\alpha} p \varepsilon \delta \rho \rho){ }^{48}$

Judging by one footnote in the works of Alexander Böhlig, the parallels with the Manichaean texts in this spell did not go unnoticed. Böhlig mentions a de-

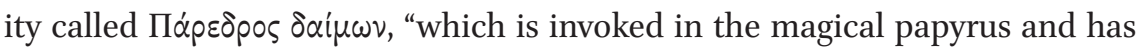
exactly the same qualities that are listed in Kephalaia". ${ }^{49}$ But he apparently compares Paredros with another Manichaean deity - the bright Twin, companion of the "Apostles". Indeed, by name and by its role the magic Paredros is a junior deity, a personal assistant.

But it can be noted, when reading this spell, that Paredros's magical possibilities are much wider here and more universal than would have been

44 See e.g. C. Bonner, Studies in Magical Amulets, Chiefly Graeco-Egyptian, Ann ArborLondon-Oxford, 1950, pp. 19, 105, 112, 113, 128-129, 137, 152, 169, 183-184.

45 Papyri Graecae Magicae. Die griechischen Zauberpapyri, hrsg. von K. Preisendanz, 2 Bde, Stuttgart, 1973-1974, Bd. 1., Nr 1, pp. 1-18.

$46 \quad$ Papyri Graecae Magicae, Bd. 1., Nr 1, line 4-148, pp. 2-10.

47 Papyri Graecae Magicae, Bd. 1., Nr 1, lines 144-146, p. 10. For an English translation, see: H.D. Betz, The Greek Magical Papyri in Translation Including the Demotic Spells, 2nd ed., Chicago, 1992, p. 7 .

48 Adversus haereses I, XXIII, 4 ; A. Rousseau, L. Doutreleau, Irénée de Lyon, Contre les hérésies. Livre I, t. II, (sc, 263), Paris, 1979, p. 318.

49 A. Böhlig, "Die Bedeutung des смc für den Manichäismus," in: Gnosis und Philosophie: Miscellanea, hrsg. von R. Berlinger, W. Schrader, Amsterdam-Atlanta, GA, 1994, S. 49. 
supposed for this relatively modest function. Moreover, such characteristics as "there is nothing without him" and "everything is subject to him" do not accord with the role of a lower deity. By his comprehensive properties, by his names in epiclesis and by iconography (i.e., just by the affinity to the Manichaean King of Darkness) Paredros reveals the distinct features of a supreme god-cosmocrator. These characteristics are used in magical literature, perhaps as a kind of flattery to the conjured deity or spirit - in order to appease him so that he would agree to serve.

In the list of Paredros' magical possibilities, one can find close analogues to the King of Darkness properties in Kephalaia: invulnerability, power over metals and partly over the elements, over different types of food (cf. in the Manichaean treatise: "five tastes" as spawns of five dark elements).

It is interesting that some of the properties that the Manichean King or his demons themselves possess correspond to the properties that Paredros gives to the magician. Thus, the zoomorphic hypostases of the King and his supreme demons, their functions as lords of the five elements ${ }^{50}$ can be compared with the ability of Paredros to turn the caster into any living creature, allowing him to move in different elements, etc.

These parallels can be summarized in table 1 (with reference to the corresponding lines of both sources):

As we can see, the order of enumeration of properties also coincides in many cases.

Parallelism is also found in the endings of both texts. Manichaean chapters end with admonition to stay away from the King of Darkness, so that not to pass into his dominion after death, "break loose their chains and their chastenings forever"51 and ascend to the highest world. ${ }^{52}$ The ending of the "Paredros spell" contains a promise that after the caster's death Paredros-Assistant will lift his spirit to the upper world.

It can be concluded that the spell of Paredros and the attached description of his iconography are generated by the same syncretic Late Antique tradition, to which go back both the iconography of the "Mithraistic Eon", and the image of the King of Darkness in Kephalaia. Such an assumption helps to understand where some features of the image of the Manichaean demon come from and how they are caused. And, judging by the textual parallels, it is not just a complex of representations, but a text or a group of texts in combination with iconography.

50 See also Kephalaia I, ed. Polotsky, Böhlig, p. 33·9-33.

$5^{1} \quad$ Kephalaia I, ed. Polotsky, Böhlig, p. 34.11-12.

$5^{2} \quad$ Kephalaia I, ed. Polotsky, Böhlig, p. 79.10-12. 
TABLE $1 \quad$ Parallels

King of Darkness

Is called "Lord of the Smoke", i.e. the dark Is called "air spirit" [Papyri Graecae element corresponding to the light element of Air [Kephalaia, p. 97-98]

His demons are male and female, he begets the love attraction [ibid., passim]

Throws demons down [p. 32.22-26] Overthrows and destroys [98-99]

He is the lord of metals; his body and the Delivers gold, silver, and copper to the bodies of his demons are gold, silver, caster [99-100]

copper, etc. [33.1-34.1]

He can become invisible [31.19-22] Makes the caster invisible [102]

He is the lord of the elements [passim] "Delivers fire and water" [103]

He is the master of „five tastes" - sweet, Delivers any kind of food, arranges feasts salty, sour, etc. [33.4-34.1] [103-114]

Dominates the demons [passim] Dominates the demons [114]

Impregnable to teeth and claws [78.18- Tames beasts, breaks the teeth of snakes 23] [115-116]

He can become hot on his own fire or become cold as snow [78.23-27]

Makes warm cold and vice versa; ignites, makes water "solid", i.e., obviously, ice [124-125]

He has the appearance of all species of living beings: beast, bird, reptile, fish, bipedal demon [30.33-3 1.1, 77.29-78.1]

He can move in any element: walk, fly, swim, crawl [78.3-10]

He guesses the thoughts of the demons facing him $[32.1-13,78.27-32]^{\mathrm{a}}$
Turns the caster into any living creature - four-legged, fish, beast, bird, reptile [119-124]

Carries the caster through various elements, gives him the ability to move in these elements [119]

Can guess the thoughts of people asking the spellcaster [175]

a Such a property of the supreme demon as omniscience is corrected in the Manichaeism: the true wisdom and omniscience are characteristic of the light deities. Obviously, therefore in the Manichaean text, the knowledge of King Darkness is depicted as limited. 
A comparison of these descriptions suggests that Paredros and two celestial birds from the 2nd book of Enoch may belong to the same branch of the tradition, and this branch was an earlier one: as for good and evil, the birds are good, higher spirits, Paredros is a rather neutral deity (however, one of the main differences between magic and religion is that magic is beyond ethics). The Gnostic, Manichean, and Mandaean leontocephals are inferior forces, the latter two are evil ones. It is not entirely clear what is the "Mithraistic Aeon" in this respect: a rich iconographic material is preserved from Mithraism, but, unfortunately, with almost no texts. Perhaps the "Mithraistic Aeon" is neither the highest god, nor completely evil, because by his iconography he looks like a ruler of the cosmos, and adherents of the cult of Mithras hardly had considered the material world with the same pessimism as the Gnostics.

It is possible, to suggest the following pattern of the evolution. Two branches originated from a certain syncretic Hellenistic deity-cosmocrator (with solar features): 1) the image of the (solar) air spirit of apocalyptic literature, and from the latter - the Gnostic ruler of the material cosmos and the Manichaean king of demons; 2) the magic character - the air spirit, i.e. Paredros.

But there is another remarkable detail. It is known that the Manichaeism condemned and prohibited magic no less than other Christian confessions and the Judaism. This is evidenced, for example, by an-Nadīm ${ }^{53}$ and Šahrastānī. ${ }^{54}$ But Kephalaia contain almost no mention of magic, no condemnations of sorcery, etc. Only in the descriptions of the King of Darkness there are numerous references to magic: it is repeatedly emphasized that he is a powerful sorcerer, a founder and master of all witchcraft and divination. ${ }^{55}$ This leads to the conclusion that the prototype of Manichaean (and perhaps also the Mandaean) king of demons was an image that had already been elaborated in some magical text.

It is easy to suggest the following line of succession: from the Hellenistic "air deity" to the lord of the cosmos (of the lower celestial spheres) in mystical teachings, to the magical omnipotent spirit and then to the king of demons in Mesopotamian magic, Manichaeism and Mandaeism.

The Manichaean elemental system consists of two pentads - five light elements and five of their dark opposites. Smoke is the dark counterpart of the

53 G. Flügel, Mani, seine Lehre und seine Schriften, Leipzig, 1862, S. 95-96; English tr.: The Fihrist of al-Nadim, A Tenth-Century Survey of Muslim Culture, ed. and transl. B. Dodge, New York-London, 1970, vol. 2, p. 789 .

54 Šahrastānī, Livre des religions et des sectes. Traduit avec introduction et notes par D. Gimaret et G. Monnot, Paris, 1986, p. 61.

55 Kephalaia I, ed. Polotsky, Böhlig, pp. 31.16-30, 34.2-5, 78.16-18. 
light element of air. Therefore, the prototype of the King of Smoke must be sought among some spirits of air. ${ }^{56}$

$5^{6} \quad$ I take this opportunity to express my gratitude to Prof. Victor Nemchinov for his help in preparing the English version of this article. 